and developing exact methods of eradicating it. This prejudfee, however, is not found in the younger men, many of whom have visited America. P. C. Clemensen, M.D.

\section{One Standard of Medical Licensure Asked in New York.}

60 E. 77th St., New YorK, FEr. 8, 1907.

To the Editor:-Year after year the medical profession of New York has been called on to oppose the passage of laws creating state examining boards in osteopathy, dermapathy, optometry and so on. Year after year we have succeeded in convineing the legislature that the passage of such laws would be unwise, but, in answer to the inquiries of senators and assemblymen, "What are you going to do with these people who besiege us each year?" we have answered, "Let them comply with the present law and then practice any method they choose." Then has come the second pertinent query, "The homeopaths have a separate board, why should not the osteopaths be granted the same privilege if they will comply with all the requirements excepting treatment?"

As the result of all this a bill has been drawn up, which is endorsed by the State Department of Education, and many leading members of the legislature, accurately defining the practice of medicine and providing for a single examining board, before which all who desire to practice the healing art must come and pass a common examination, eliminating the subject of practice, assuming that all who have the other necessary qualifications will be able to practice intelligently the method which seems to be indicated in the cases they meet.

It is not expected that the enactment of this law is going to bring about an immediate leveling of all the barriers now existing between "allopathic." homeopathic and other "pathice" physicians, although, doubtless, that will be the ultimate result. Nor will it prevent the demands in the future of peculiar classes desiring separate recognition for commercial and other reasons. It will, however, place the legislature in a position to say when future efforts to secure class legislation along medical lines are made, that the State of New York recosnizes only the ordinary educated plirsician. and the method of practice is something the individual physician must determine for himself. It will place medical practice on a higher plane, than has heretofore been accorded it. and will accomplish what our present law was designed for, and has failed to do, namely, properly protect the people of the State of New York from incompetent physicians.

Will you please request your New York readers to write their representatives in the legislature at once, urging the defeat of osteopathy, optometry and all similar bills, and the passage of the single board bill, which is Senate Bill No. 154. Assembly Bill No. 160, and to use these numbers when writing.

Frani Van Fleet, M.D.

Chairman, Committee on Legislation of the Medical Society of the County of New York.

\section{A Protest Against Compulsory Publicity.}

Rochester. Minn., Feb. 10, 1907.

To the Editor:-We have lately suffered an unwarranted intrusion into our private affairs, through the publication in certain newspapers of a sensational article furnished by a "Sunday Supplement" syndicate. Up to the present-we have succeeded in checking several such publications. We are now taking legal steps to determine what redress if anv, may be had, and to what extent not only ourselves, but the medical profession as a whole, can be protected against such outrages on conmon deceney.

$$
\text { W. J. and C. H. MaYo. }
$$

\section{Association News}

Special Rates for the Atlantic City Session.

According to advices, one first-class fare plus $\$ 1.00$ for the round-trip, going and returning by the same routes, will prevail from points more than 100 miles from Atlantic City. Tickets will be on sale June 1 to 4 , inclusive, returning leaving Atlantic City June 4 to 10 , inclusive. A special validating agency is also promised. so it is to be hoped that there will be little trouble in this regard.

\section{Queries and Minor Notes}

Anonymous Communications will not be noticed. Querles for this column must be accompanied by the writer's name and address, but the request of the writer not to publish name or address will be faithfully observed.

NEPHRITIS COMPLICATING FXOPHTHALMIC GOITER. New York, Jan. 28, 1907.

To the Editor:-Please inform me whether Bright's disease com plicates exophthalmle golter and what influence nephritis would plicates exophthalmic golter and what influence nephritis wou
have on this condition.
CuAnuss F. D'A. Frascis.

ANSWER.-Nephritis is not recognized as a common compllcation of exophthalmic goiter; several authors do not even mention albuminuria as a symptom. Others do so but no emphasis is placed on it. Thus 'Tyson (Practice of Medicine, 3d edition, 1903, p. 675) says "Intermittent albuminuria is frequent, as pointed out by Dr. Begbie'" Moeblus, In Nothnagel's System, refers to albuminuria as being occasionally present. slight toxemic degeneration of the renal epithellum in long-continued or severe cases may explain such albuminuria. Of course, exophthalmlc goiter may appear in one who has a genuine nephritis, the association of the two conditions being purely accidental. Such a case is reported by Elliot ('He JoURNaL, June 17, 1905, p. 1897), in which exophthalmic goiter was complicated both by glycosuria and by a true nephritic albuminuria with albuminuric retinitis. In regard to the association of Bright's disease with exophthalmic goiter he says: "No direct association exists between exophthalmic golter and nephritis, although transient albuminuria has been noted during the periods of acute disturbance. Chronic Bright's disease is not numbered among the epiphenomena of exophthalmic goiter." Lastly, in exophthalmic goiter there may develop a period of cardiac incompetency from myocardial weakness. When this occurs dilatation of the heart with passive congestion of the liver and kidney, edema of the lower extremities, etc., may be present. Such a renal congestion might be accompanied by a not inconsiderable trace of albumin in the urine, and even by a few casts.

\section{THE RENGTI OF IIYODERMIC NEEDLES.}

Mahanox City, Pa., Jan. 22, 1907.

To the Editor:-I would like to have your opinion why the present hypodermic needles are made an inch to an inch and a half long. My idea is that a needle half an inch long has the advantage. that it is not so likely to puncture a superficial vein, and that it will be almost impossible to reacl an artery or nerve. The same physiologic action will result from either length.

G. W. Reese, M.D.

AxswER. - While the average Iength of the needles generally sold with hypodermic syringes may be longer than is necessary, our correspondent is in error in assiming that they measure from an inch to an inch and a half in length. The better class of manu facturers are sending out srringes equipped with needles from threequarters to one inch in length. These lengths bave been adopted because of a general demand for these sizes. Those who prefer needles of shorter length can obtain then by specifying the length they want. Modern surgical instrument catalogues Illustrate needles as short as one-quarter of an inch. Our opinion is that needles of one-half to five-eightlus of an inch in length are preferable to those of standard length.

\section{RUILS FOR FIRST AID TO TIE INJURED.}

WARRIOR, ALA., Jan. 28, 1907.

To the Editor:- Where can I obtain a formula of rules for the care of the injured around mines and brickyards-rules to be posted around the above-named places and used to instruct in first-aid to the injured? J. G. Vance, M.D

\section{THE RUSSO "REACTION."}

Denver, Jan, 31, 1907

To the Editor:-Will you tell me where I can get information regarding Russo's reaction of methylene blue in urine? I am de sirous of learning something of its nature. In the abstract in THE JOURNAL it states that the reaction "occurs as an ordinary physi"al" phenomenon in any urine.

Axswer.-The reaction referred to was proposed by Russo (Riforma Medica, May 13, 1905), and consists in adding to 4 or 5 c.c. (one dram) of urine 4 drops of a solution of methylene blue. In typhoid patients be found that the urine became a light green in the first stage, an emerald green at the height of the disease and gradually assumed a bluish green to blue color during the stage of decline and convalescence. Russo believed that the color depended on toxins present in the urine and might be made of diagnostic value. It was possible by simple experiments for $E$. Cousin and S. Costa (Presse Medicale, March 14, 1906), and also Ch. Gandy ('presse Ifedicale, March 21, 1906), to prove, what might have been suspected beforehand, that the green color was due to the mixture of the blue liquid with the yellow urine. Every. 